\title{
SISTEM INFORMASI LOWONGAN KERJA BERBASIS WEB PADA DINAS TENAGA KERJA DAN TRANSMIGRASI (DISNAKERTRANS) KOTA DUMAI
}

\author{
Nurul Ulfa ${ }^{1}$, Elisawati ${ }^{2}$, Amat Sofiyan $^{3}$ \\ ${ }^{1,2,3}$ Sekolah Tinggi Manajemen Informatika \& Komputer (STMIK) Dumai \\ Jalan Utama Karya Bukit Batrem II Dumai-Riau \\ e-mail : ulfanuru186@gmail.com ${ }^{1}$, elisawati06@gmail.com², amatsofiyan90@gmail.com³
}

\begin{abstract}
ABSTRAK
Sistem informasi lowongan pekerjaan berbasis web pada Dinas Tenaga Kerja dan Transmigrasi (Disnakertrans) Kota Dumai ini dibuat untuk membantu dalam mengatasi permasalahan tentang pencari kerja mencari informasi lowongan pekerjaan. Analisa terhadap sistem informasi lowongan pekerjaan pada Disnakertrans Kota Dumai ini meliputi pembuatan aliran sistem informasi, context diagram, data flow diagram, entity relationship diagram. Sistem informasi ini di buat menggunakan bahasa pemograman php yang sudah di Online. Sistem informasi lowongan pekerjaan berbasis web pada Kota Dumai ini menggunakan metode selection sort pada bagian gaji minimum dan gaji maksimum yang mampu mencari gaji yang sesuai keinginan pencari kerja. Dengan adanya sistem informasi lowongan pekerjaan berbasis web pada Disnakertrans Kota Dumai untuk mencari lowongan pekerjaan yang sesuai kenginan pencari kerja dan mudah mendapatkan informasi lowongan pekerjaan dari Disnakertrans Kota Dumai.
\end{abstract}

Kata kunci : Sistem, Informasi, Lowongan Pekerjaan, Web

\section{ABSTRACT}

A Web-based job vacancy information system at the Department of Manpower and Transmigration (Disnakertrans) of Dumai City was created to assist in overcoming problems regarding job seekers seeking job vacancy information. Analysis of job vacancy information systems in Dumai City Disnakertrans includes making information systems flow, context diagrams, data flow diagrams, entity relationship diagrams. This information system is made using the PHP programming language that is already online. This web-based job vacancy information system in Dumai City uses a selection sort method on the part of the minimum salary and maximum salary that is able to find the salary that suits the job seeker. With the web-based job vacancies information system in Dumai City Disnakertrans to find job vacancies that fit the job seeker's desire and easily get job vacancies information from Dumai City Disnakertrans.

Keywords: Information Systems, Job Vacancies, Selection Sort.

\section{PENDAHULUAN}

Di zaman sekarang ini teknologi informasi sangatlah berkembang dengan cepat. Orangorang cenderung menggunakan teknologi informasi digital di dalam mencari suatu informasi ataupun menyampaikan suatu informasi. Penyampaian informasi saat ini merupakan hal penting dalam perkembangan teknologi secara digital.
Disnakertrans Kota Dumai merupakan suatu instansi pemerintahan pelayanan masyarakat yang memiliki peranan sebagai wadah pasar kerja antara para pencari kerja dengan para pengguna perusahaan khususnya di Kota Dumai. Saat ini Disnakertrans Kota Dumai dalam memfasilitasi antara para pencari kerja dan perusahaan yang memberikan informasi pekerjaan masih dilakukan dengan papan pengumuman. Namun kenyataannya Disnakertrans Kota Dumai masih belum memanfaatkan teknologi digital untuk 
I N F O R M A I K A

Jurnal Informatika, Manajemen dan Komputer, Vol. 12 No. 1, Mei 2020

elSSN : 2580-3042

pISSN : 1979-0694

mempermudah pencari kerja dalam mendapatkan informasi lowongan kerja dan perusahaan untuk menginformasikan lowongan yang tersedia. Disnakertrans Kota Dumai dalam pendataan perusahaan masih melakukan proses pendataan secara manual.

\section{a. Informasi}

Informasi adalah data yang telah di diolah menjadi sebuah bentuk yang berarti bagi penerimanya dan bermanfaat dalam pemgambilan keputusan (Sihombing \& Khumaini, 2016)

\section{b. Sistem Informasi}

Sistem Informasi adalah satuan komponen yang saling berhubungan yang mengumpulkan atau mendaptkan kembali, memproses, menyimpan dan mendistribusikan informasi untuk pendukung pengambilan keputusan dan kendali dalam suatu organisasi (Andriani, Ridarmin, \& Kurniawan, 2018).

\section{c. Lowongan Kerja}

Lowongan Kerja adalah Sebuah Kesempatan kerja pada posisi tertentu di instansi atau tempat usaha yang tersedia untuk individu maupun kelompok yang telah memenuhi persyaratan yang dibutuhkan (Nugroho, Zukfikar, \& Sujono, 2019).

\section{d. Basis Data}

Basis data adalah kumpulan data yang saling berelasi. Data sendiri merupakan fakta mengenai obyek, orang, dan lain-lain. Data dinyatakan dengan nilai (angka, deretan karakter, atau symbol). (Kusrini, 2007:2)

\section{e. PHP}

PHP memiliki kepanjangan PHP Hypertext Preprocessor, merupakan suatu bahasa pemrograman yang fungsinya untuk mebangun suatu website dinamis. PHP menyatu dengan kode HTML, maksudnya adalah beda kondisi. HTML digunakan sebagiai pembangun atau pondasi dari kerangka layout web, sedangkan PHP difungsikan sebagai prosesnya, sehingga adanya PHP tersebut, sebuah web akan lebih mudah di-maintenance. (Saputra \& Agustin, 2013:2)

\section{f. Website}

Website atau situs dapat diartikan sebagai kumpulan halaman-halaman yang digunakan untuk menampilkan informasi teks, gambar diam atau gerak animasi, suara, atau gabungan dari semuanya, baik yang bersifat statis maupun dinamis yang membentuk satu rangkaian bangunan yang saling terkait, yang masing-

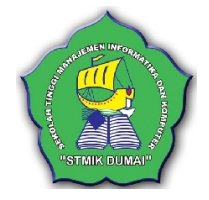

masing dihubungkan dengan jaringan-jaringan halaman. Hubungan antara satu halaman web dengan halaman web yang lainnya disebut Hyperlink, sedangkan teks yang dijadikan media penghubung disebut Hypertext. (Hidayat, 2010:2)

\section{METODOLOGI PENELITIAN}

Metode penelitian berisikan kerangka kerja atau tahapan yang merupakan dasar langkahlangkah yang akan digunakan dalam penelitian, sehingga tahap yang akan dilakukan akan sesuai dengan aturan dan tersusun secara sistematis, logis, terstruktur dan teratur. penelitian ini menggunakan model waterfall. Adapun kerangka kerja dalam penelitian ini digambarkan sebagai berikut:

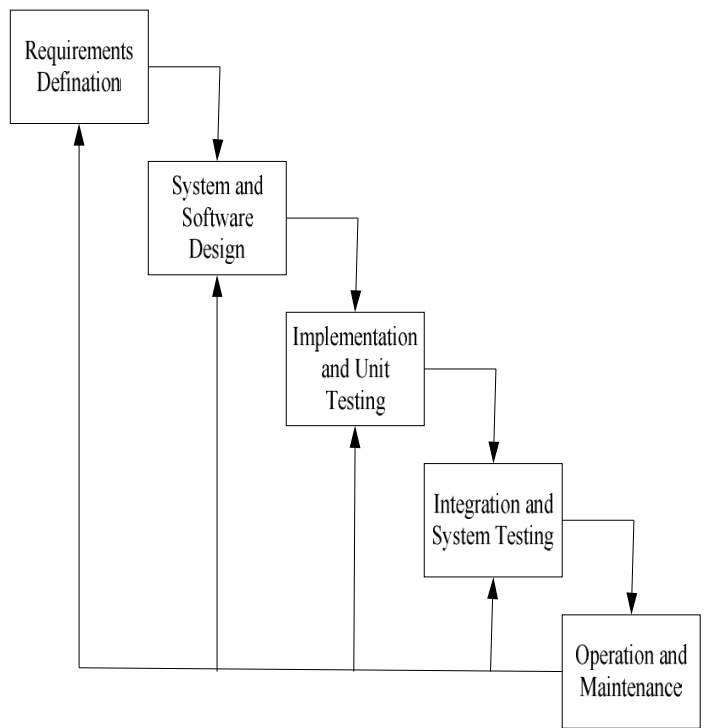

Gambar 1. Model Waterfall

Sumber : (Sasmito, 2017:8)

Adapun penjelasan kerangka penelitian pada gambar 1. Adalah sebagai berikut:

1. Requirements analysis and definition (Definisi kebutuhan sistem)

Dalam tahap ini penulis melakukan analisis mendalam tahapan sistem yang sedang berjalan saat ini, sehingga penulis bisa memahami dengan baik proses yang terjadi. Sehingga akan mempermudah penulis didalam membuat sistem informasi lowongan pekerjaan pada Disnakertrans Kota Dumai.

2. System and software design (Desain sistem dan perangkat lunak)

Sistem informasi lowongan pekerjaan berbasis web pada Disnakertrans Kota Dumai dibangun menggunakan PHP dan desain sistem menggunakan ASI, Context Diagram, Data Flow Diagram. 
I N F O R M A I K A

Jurnal Informatika, Manajemen dan Komputer, Vol. 12 No. 1, Mei 2020

eISSN : 2580-3042

pISSN : 1979-0694

3. Implementation and Unit Testing (Implementasi dan pengujian unit)

Penulisan kode program merupakan tahap penerjemahan desain sistem yang telah dibuat ke dalam bentuk perintah-perintah yang dimengerti komputer.

4. Integration and system testing (Integrasi dan pengujian sistem)

Pengujian software dilakukan untuk memastikan bahwa software yang dibuat telah sesuai dengan desainnya dan semua fungsi dapat dipergunakan dengan baik tanpa ada kesalahan. Dalam tahap ini, Disnakertrans Kota Dumai harus memastikan bahwa kerangka pengujian software dibuat dengan lengkap meliputi semua proses. Kebutuhan dan pengendalian yang ada di dalam dokumen analisa kebutuhan dan desain sistem.

5. Operation and maintenance (Operasi dan pemeliharaan)

Pada tahapan ini penulis melakukan beberapa hal yang dapat mendukung agar program yang telah dibuat dapat digunakan secara maksimal yaitu dengan cara mendokumentasikan semua informasi tentang program dan melakukan pemeliharaan terhadap program yang telah dibuat.

\section{HASIL DAN PEMBAHASAN}

a. Aliran Sistem Informasi Baru (ASI Baru)

Aliran sistem informasi yang telah di implemetasikan ke sistem adalah sebagai berikut:

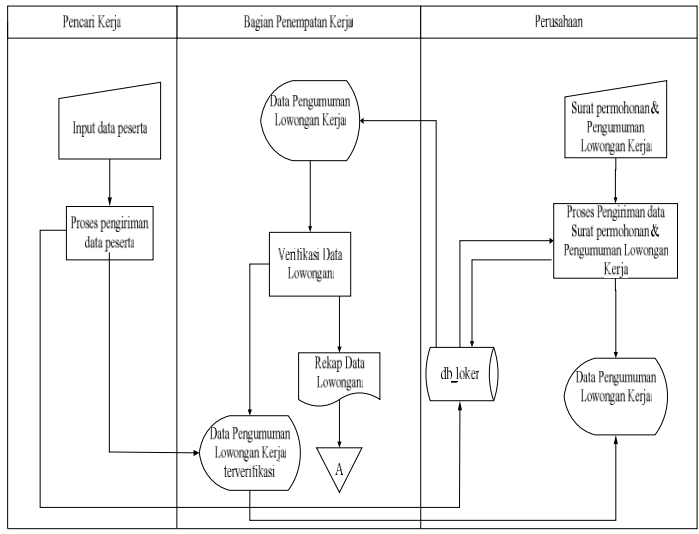

Gambar 2. ASI Baru

Penjelasan dari aliran sistem informasi di atas adalah : perusahaan menginput dan mengirim surat permohonan dan pengumuman lowongan kerja. Kemudian sistem melakukan proses pengiriman data surat permohonan dan pengumuman lowongan kerja, menghasilkan dua rangkap laporan data pengumuman lowongan kerja pertama ke perusahaan dan kedua ke bagian

penempatan kerja. Kemudian pada bagian penempatan kerja memverikasi data lowongan. Menghasilkan laporan data pengumuman lowongan kerja. Dilakukan pengumuman lowongan kerja menghasilkan dua rangkap laporan data lowongan kerja direkap kemudian diarsipakan, satu rangkap diumumkan di sistem data pengumuman lowongan kerja yang terverifikasi.

\section{b. Context Diagram}

Context Diagram dapat di lihat pada gambar 3, sebagai berikut :

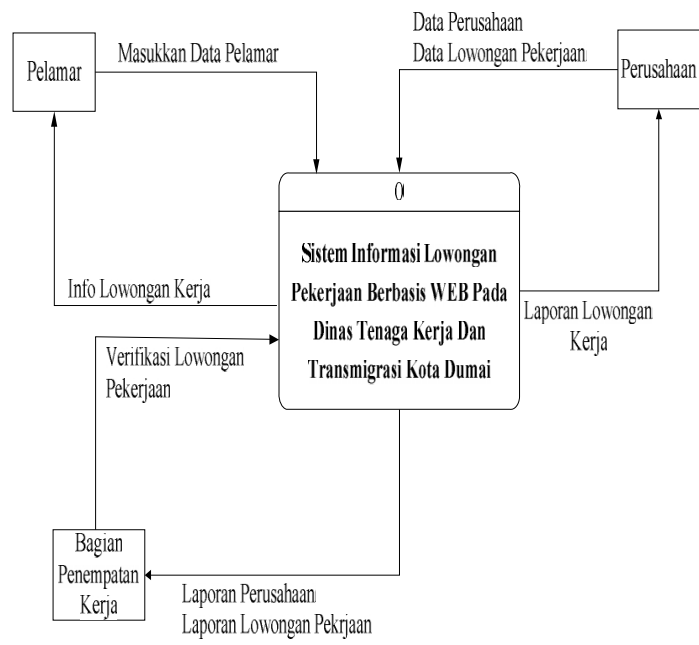

Gambar 3. Context Diagram

Berikut ini adalah penjelasan alur context diagram-nya yaitu:

1. Perusahaan memasukkan data perusahaan dan data lowongan pekerjaan, kemudian Disnakertrans memverifikasi lowongan pekerjaan.

2. Selanjutnya setelah diverifikasi lowongan pekerjaan, perusahaan mendapatkan laporan lowongan pekerjaan dan Disnakertrans mendapatkan laporan perusahaan dan laporan lowongan pekerjaan yang akan dipublikasi pada pencari kerja.

3. Kemudian pelamar memasukkan data pelamar yang ada pada informasi lowongan pekerjaan yang akan dilamar-nya dan yang terakhir jika lamaran pencari kerja diterima oleh perusahaan maka perusahaan akan memberitahukan informasi lowongan pekerjaan lewat gmail atau nomor telephone pelamar.

\section{c. Data Flow Diagram}

Menurut Kristanto (2010:115), Data Flow Diagram (DFD) disebut juga dengan Diagram Arus Data (DAD). DFD adalah: suatu model 
I N F ORM A I K A

Jurnal Informatika, Manajemen dan Komputer, Vol. 12 No. 1, Mei 2020

elSSN : 2580-3042

pISSN : 1979-0694

logika data atau proses yang dibuat untuk menggambarkan: darimana asal data, dan kemana tujuan data yang keluar dari sistem, dimana data disimpan, proses apa yang menghasilkan data tersebut, dan interaksi antara data yang tersimpan, dan proses yang dikenakan pada data tersebut. (Afyenni, 2014).

Data Flow Diagram dapat di lihat pada gambar 4, sebagai berikut :

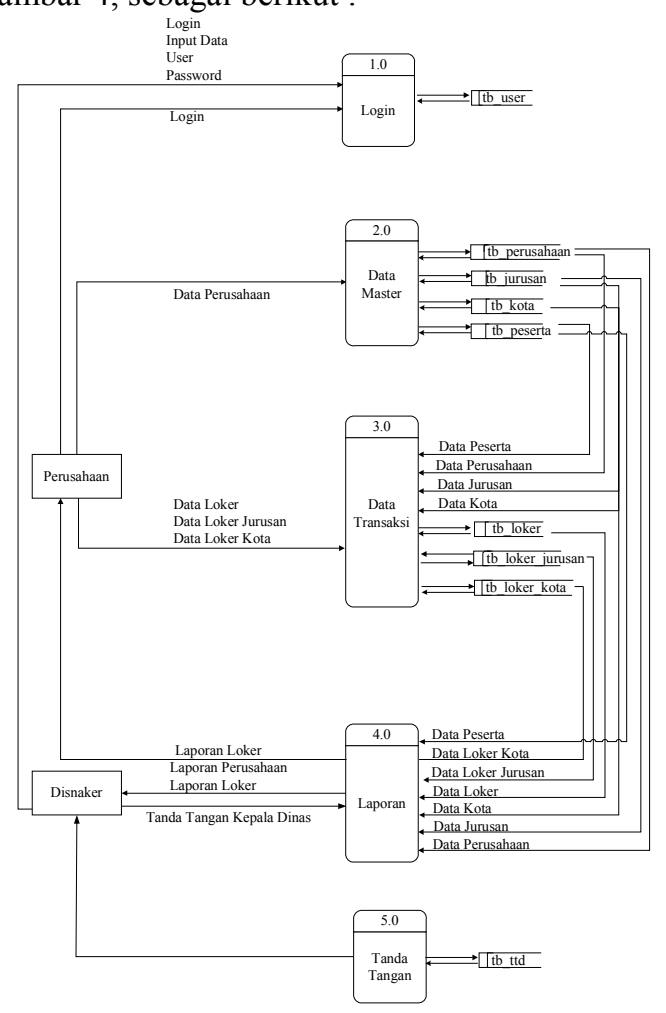

Gambar 4. Data Flow Diagram

Berikut ini adalah penjelasan alur data flow diagram-nya yaitu:

1. Disnakertrans dan perusahaan pada proses login yg terdapat pada tabel login harus login terlebih dahulu untuk membuka hak akses masing - masing.

2. Perusahaan menginputkan data perusahaan yang terdiri dari data master yaitu tabel perusahaan, tabel jurusan, tabel kota dan tabel peserta. Kemudian pada tabel - tabel data master mengirimkan data - datanya ke data transaksi.

3. Pada entity perusahaan terdapat transaksi yaitu data loker, loker jurusan dan loker kota yang akan menghasilkan laporan ke Disnakertrans dan pada data master yang terdiri dari tabel perusahaan, tabel jurusan, tabel kota dan tabel peserta akan menghasilkan laporan ke Disnakertrans.

4. Pada proses laporan yang akan menghasilkan laporan nya ke entity perusahaan yaitu data loker dan data perusahaan.

5. Pada proses tanda tangan yang diinput oleh Disnakertrans akan menghasilkan tanda tangan pada laporan perusahaan dan laporan lowongan pekerjaan.

\section{d. Tampilan Program}

1. Form Menu Home

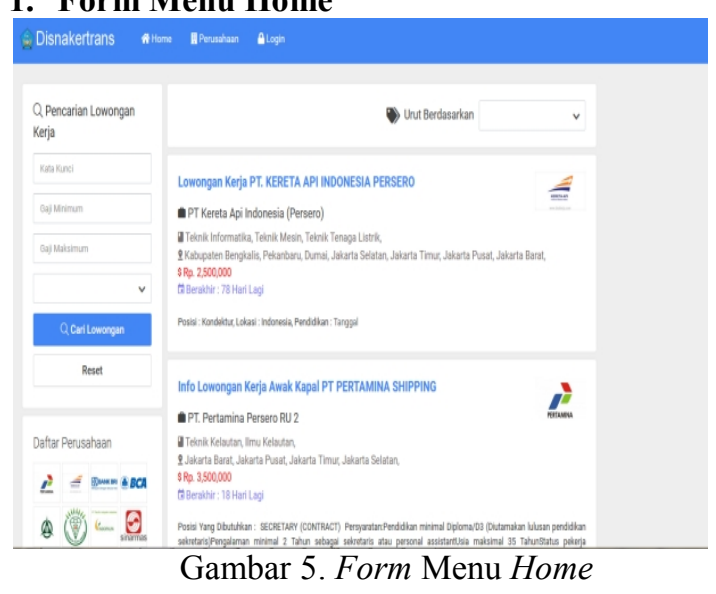

\section{Form Login Admin}

Jalankan program aplikasi pada admin dengan cara mengklik icon login. Setelah itu akan muncul form login. Masukkan username, password dan pilih hak akses admin. Jika telah diisi dengan benar, maka program aplikasi utama terbuka jika tidak sesuai akan muncul pesan username tidak terdaftar.

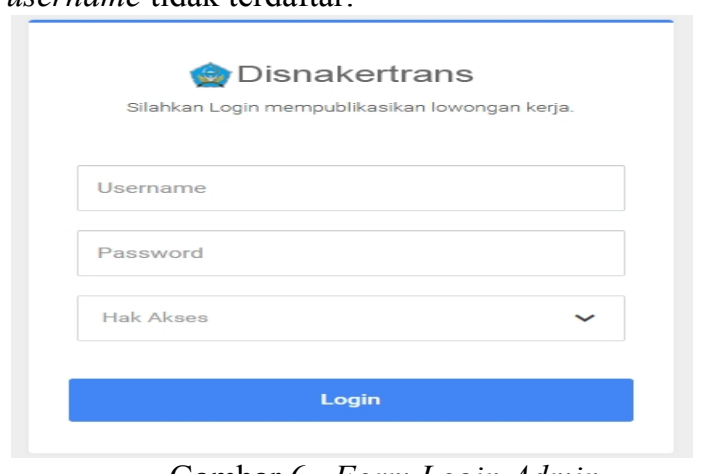

Gambar 6. Form Login Admin

\section{Form Input Data Perusahaan}

Dalam menu perusahaan pada tombol button tambah perusahaan untuk mendaftarkan akun perusahaan yang terdiri dari nama perusahaan, username dan password. 
I N F ORM A I K A

Jurnal Informatika, Manajemen dan Komputer, Vol. 12 No. 1, Mei 2020

elSSN : 2580-3042

pISSN : 1979-0694

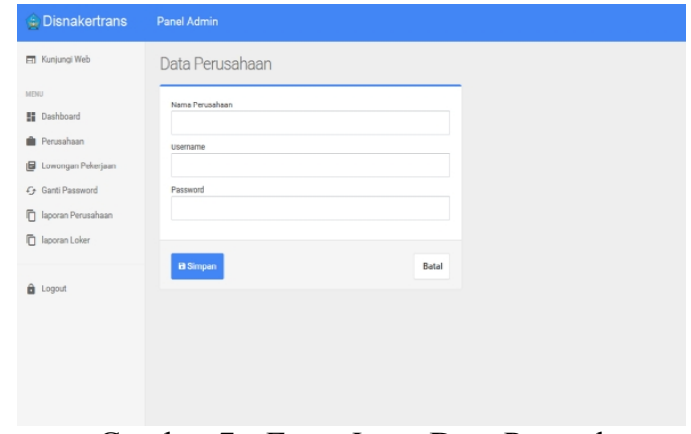

Gambar 7. Form Input Data Perusahaan

\section{Form Login Perusahaan}

Jalankan program aplikasi pada perusahaan dengan cara mengklik icon login. Setelah itu akan muncul form login. Masukkan username, password dan pilih hak akses perusahaan. Jika telah diisi dengan benar, maka program aplikasi utama terbuka jika tidak sesuai akan muncul pesan username tidak terdaftar.

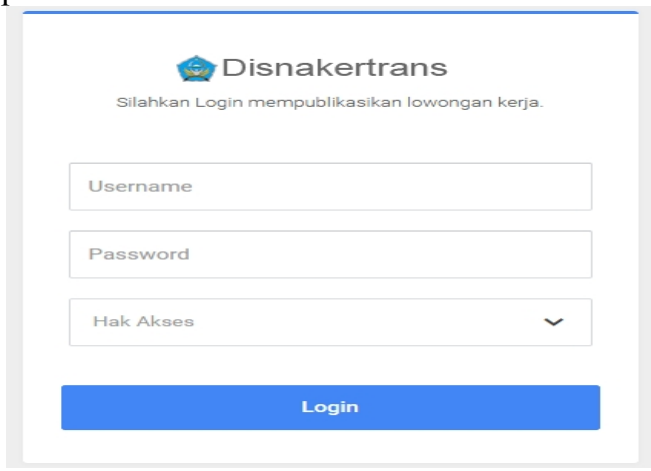

Gambar 8. Form Login Perusahaan

\section{Form Menu Profil Perusahaan}

Pada form ini perusahaan dapat memasukan data profil perusahaan, langkah-langkahnya yaitu input nama perusahaan, alamat, kota, provinsi, nomor telepon, email, kemudian klik pilih gambar logo perusahaan, klik gambar sampul perusahaan dan input deskripsi perusahaan selanjutnya klik simpan.

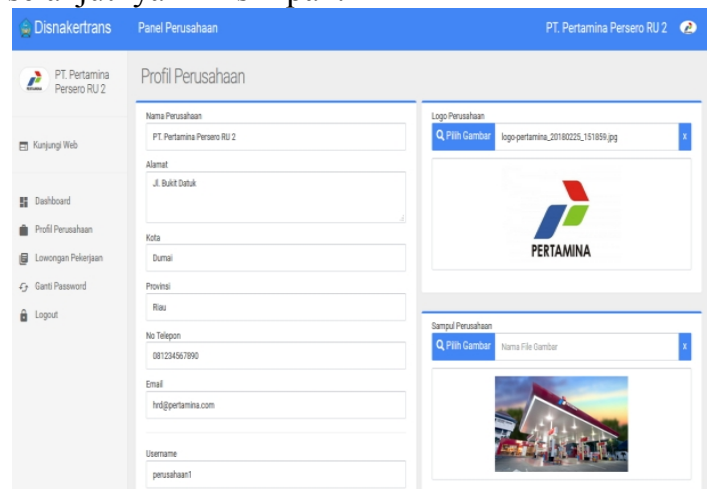

Gambar 9. Form Menu Profil Perusahaan

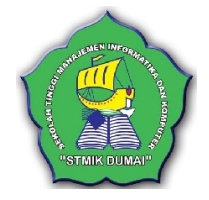

6. Form Input Tambah Lowongan Pekerjaan

Dalam menu lowongan pekerjaan pada tombol button tambah lowongan pekerjaan ini perusahaan dapat memasukan lowongan pekerjaaan langkah-langkahnya yaitu sebagai berikut :

a. Input judul lowongan pekerjaan, kemudian klik pilih gambar surat permohonan pengumuman lowongan kerja, klik gambar poster pengumuman lowongan kerja dan input deskripsi perusahaan selanjutnya klik simpan

b. Selanjutnya, input jabatan yang ditawarkan, prakiraan gaji, lokasi penempatan, pendidikan minimal, jurusan, jumlah diperlukan, hari kerja, jam kerja, kemudian tentukan tanggal dan bulan sampai berlakunya informasi lowongan pekerjaan.

c. Kemudian, klik kirim lowongan kerja.

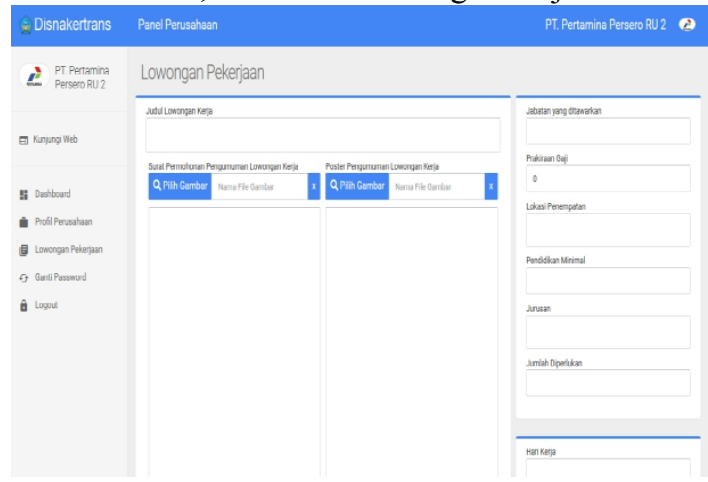

Gambar 10. Form Input Tambah Lowongan Pekerjaan

\section{Form Data Lowongan Pekerjaan pada Admin}

Dalam menu lowongan pekerjaan pada admin ini terdapat data lowongan pekerjaan yang dikirim dari perusahaan yang akan dipublikasi atau diriview oleh admin.

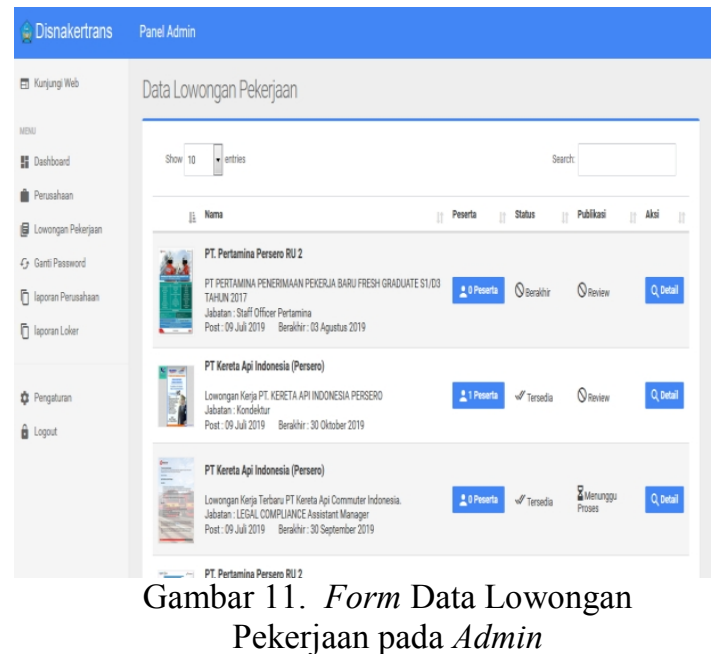


I N F ORM A I K A

Jurnal Informatika, Manajemen dan Komputer, Vol. 12 No. 1, Mei 2020

eISSN : 2580-3042

pISSN : 1979-0694

\section{Form Input Ubah Data Lowongan}

Pekerjaan

Dalam menu lowongan pekerjaan pada tombol button detail ini jika lowongan pekerjaan perusahaan di riview oleh admin maka perusahaan harus memperbaiki data lowongan pekerjaannya atau dihapus lowongan pekerjaannya, kemudian klik perbaharui lowongan kerja.

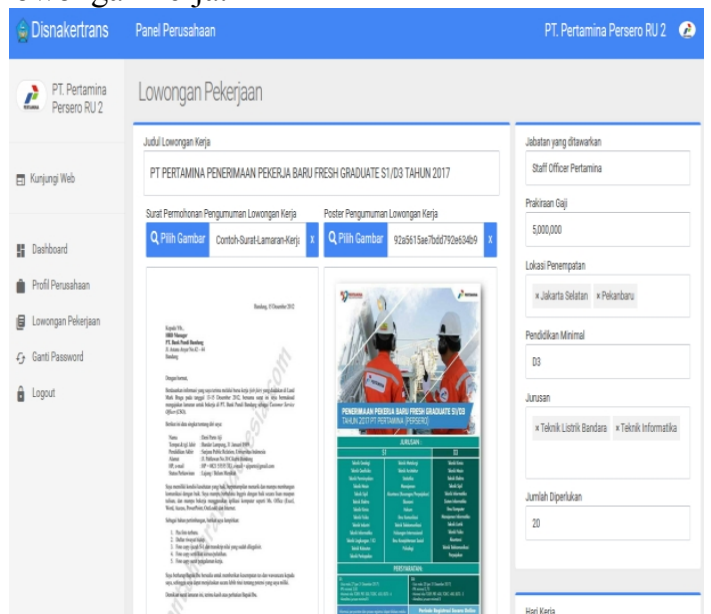

Gambar 12. Form Input Ubah Data Lowongan Pekerjaan

\section{Form Laporan Perusahaan}

Proses pada menu ini berfungsi untuk menampilkan laporan perusahaan pertanggal, perbulan dan pertahun. Laporan hanya bisa dilihat oleh admin, berikut langkah-langkah menampilkan data absen perusahaan pertanggal, perbulan dan pertahun adalah sebagai berikut :

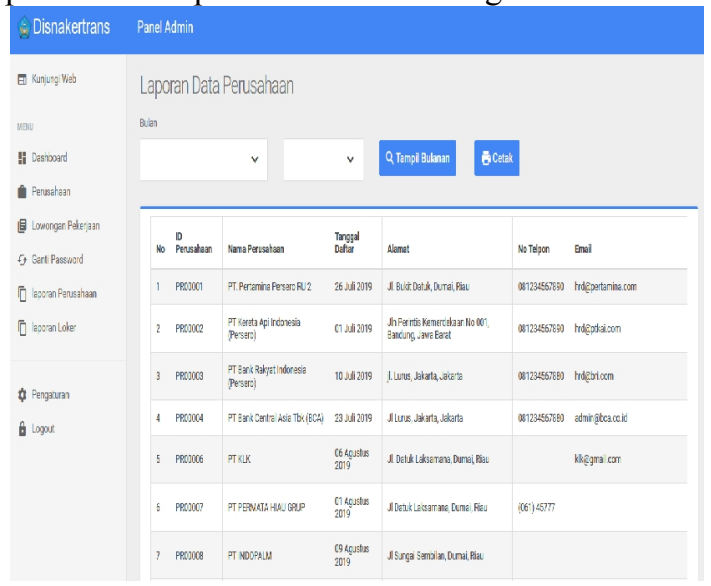

Gambar 13. Form Laporan Perusahaan

\section{Form Laporan Lowongan Kerja}

Proses pada menu ini berfungsi untuk menampilkan laporan lowongan kerja pertanggal, perbulan dan pertahun. Laporan hanya bisa dilihat oleh admin, berikut langkah-langkah

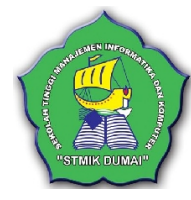

menampilkan data absen lowongan kerja pertanggal, perbulan dan pertahun adalah sebagai berikut :

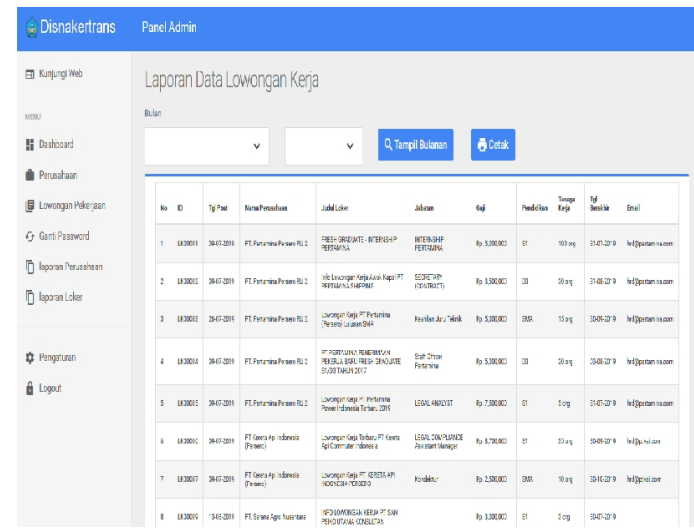

Gambar 14. Form Laporan Perusahaan

\section{Form Ganti Password pada Admin}

Dalam menu ini admin bisa ganti password sesuai keinginannya dan lebih aman.

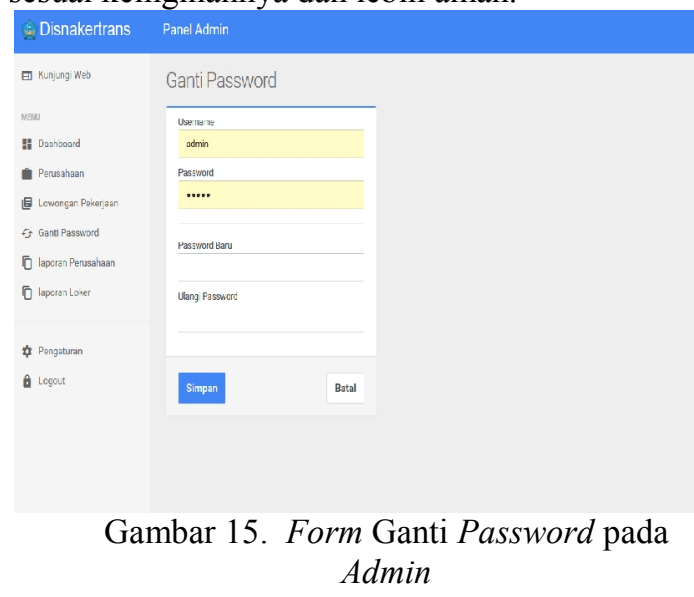

\section{Form Ganti Password pada Perusahaan}

Dalam menu ini perusahaan bisa ganti password sesuai keinginannya dan lebih aman.

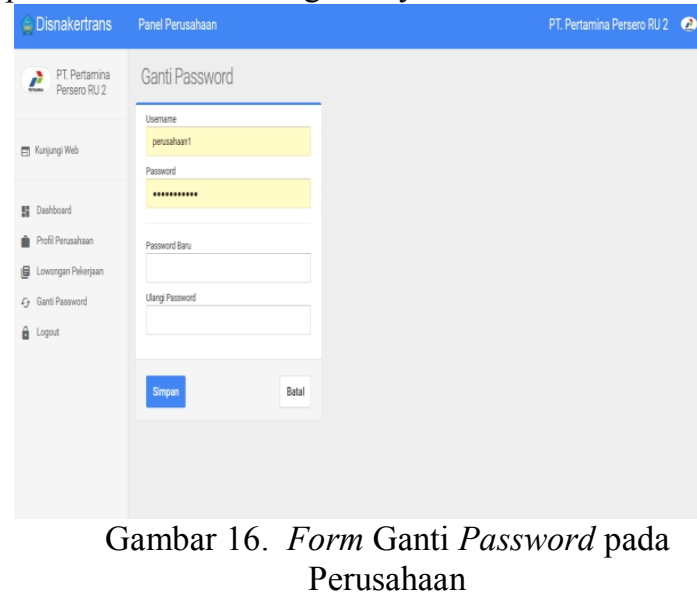


I N F ORM A I K A

Jurnal Informatika, Manajemen dan Komputer, Vol. 12 No. 1, Mei 2020

eISSN : 2580-3042

pISSN : 1979-0694

\section{Form Menu Perusahaan}

Dalam menu perusahaan menampilkan beberapa perusahaan-perusahaan yang sudah mempublikasi lowongan pekerjaannya.

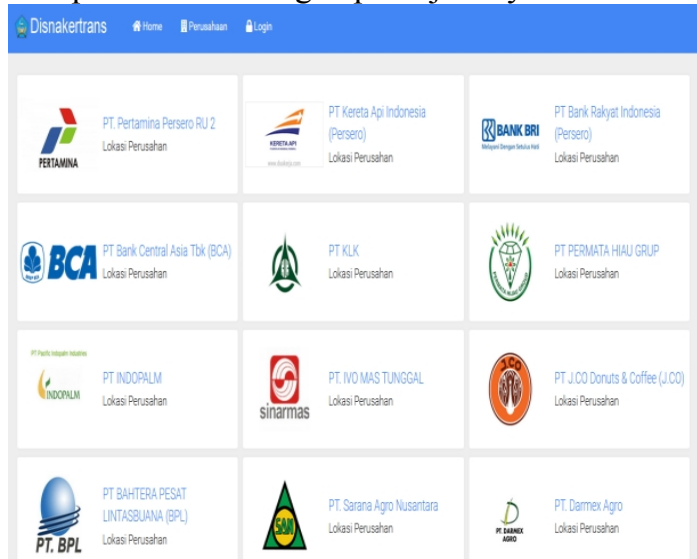

Gambar 17. Form Menu Perusahaan

\section{Form Informasi Perusahaan}

Dalam form informasi perusahaan ini menampilkan informasi perusahaan yang terdiri dari nama perusahaan, alamat, no telepon atau email dan deskripsi perusahaan serta informasi lowongan pekerjaan perusahaan tersebut.

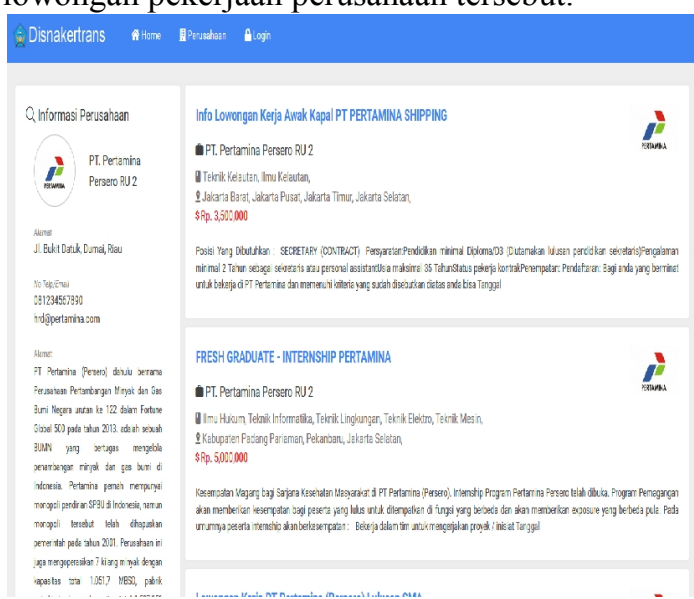

Gambar 18. Form Informasi Perusahaan

\section{Form Lowongan Pekerjaan}

Dalam form lowongan pekerjaan ini menampilkan informasi lowongan pekerjaan perusahaan yang terdiri dari nama perusahaan, berakhir lowongan pekerjaan, gaji, jabatan, lokasi, deskripsi perusahaan, penempatan pekerjaan, lainnya, brosur lowongan kerja dan deskripsi perusahaan serta informasi lowongan pekerjaan lain.

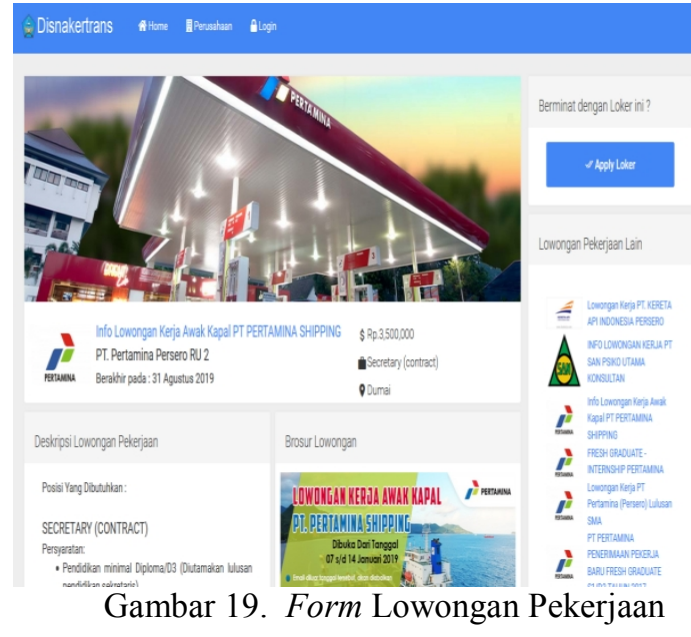

\section{Form Data Peserta}

Dalam form data peserta ini pencari kerja bisa melamar pekerjaan dengan meinput data diri kemudian dikirim di perusahaan tersebut, selanjutnya perusahaan akan menghubungi pencari kerja tersebut.

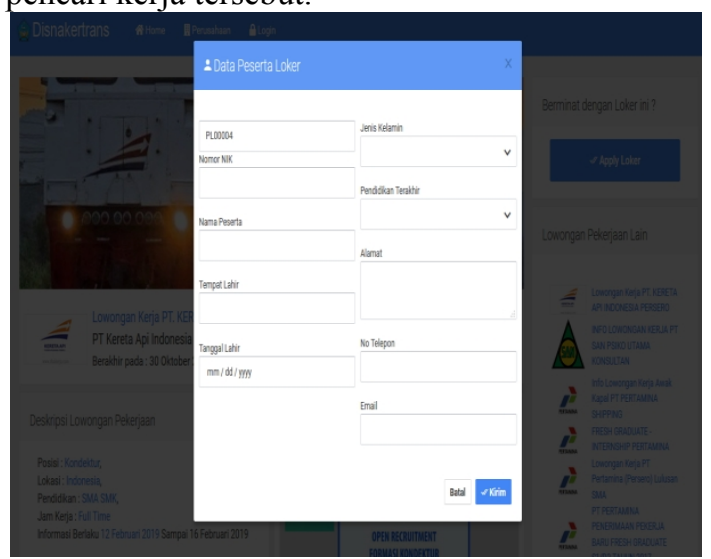

Gambar 20. Form Data Peserta

\section{Form Pengaturan}

Dalam form data peserta ini untuk mengatur nama kepala dinas dan NIP kepala dinas pada laporan.

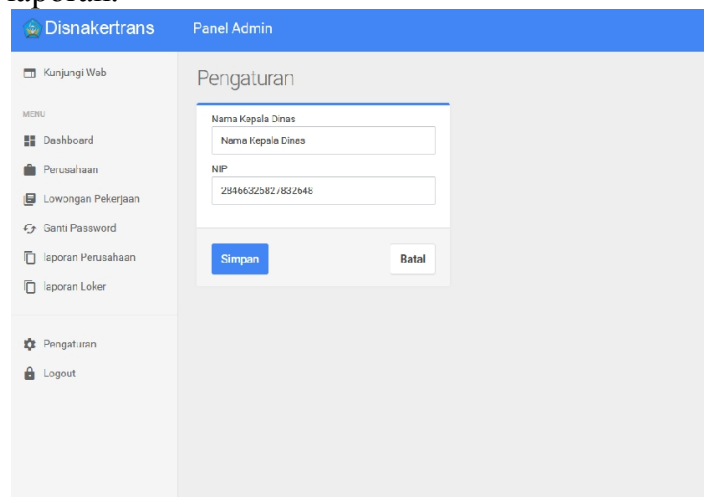

Gambar 21. Form Pengaturan 
I N F ORM A I K A

Jurnal Informatika, Manajemen dan Komputer, Vol. 12 No. 1, Mei 2020

eISSN : 2580-3042

pISSN : 1979-0694

\section{Form Laporan Perusahaan}

Dalam form ini menghasilkan laporan seluruh perusahaan mulai dari pertanggal, perbulan hingga pertahun.

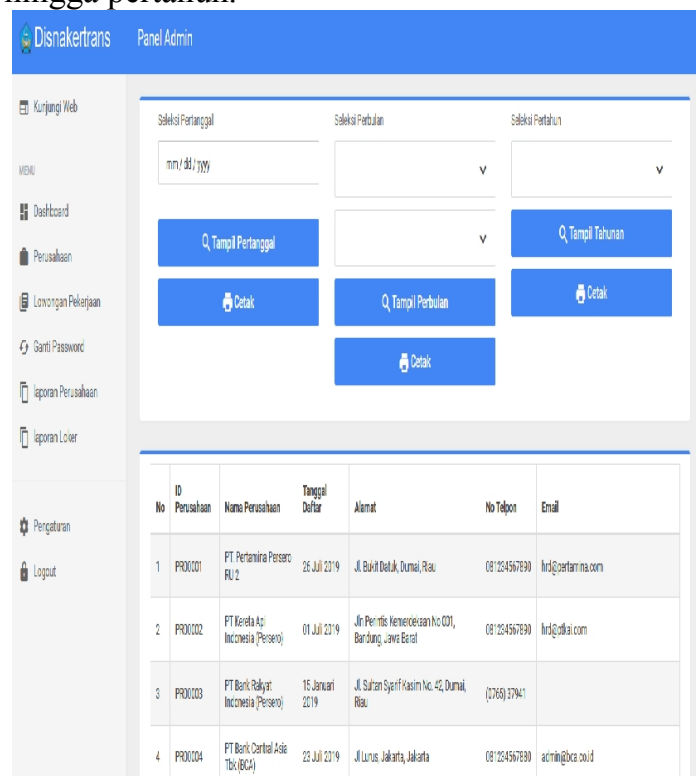

Gambar 22. Form Laporan Perusahaan

\section{Form Laporan Lowongan Kerja}

Dalam form ini menghasilkan laporan seluruh perusahaan yang didalamnya terdiri dari pertanggal, perbulan hingga pertahun.

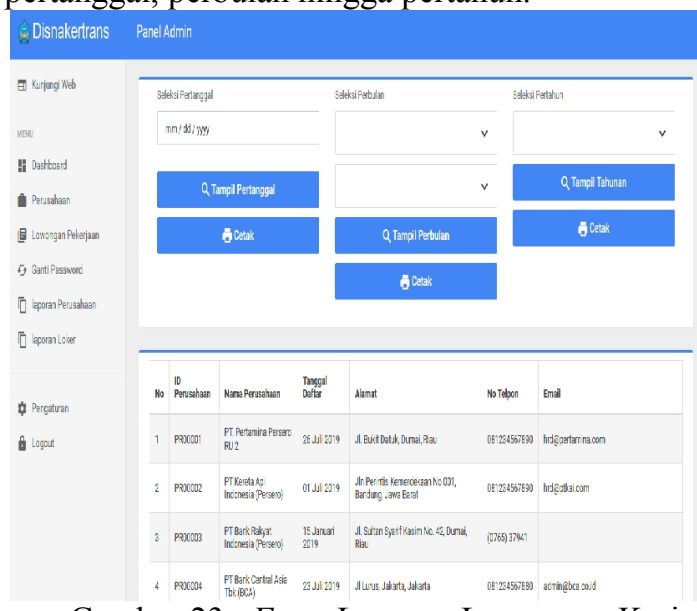

Gambar 23. Form Laporan Lowongan Kerja

\section{KESIMPULAN}

Dengan dibuatnya sistem informasi lowongan pekerjaan berbasis web pada Disnakertrans Kota Dumai yang berfungsi untuk memberikan informasi lowongan pekerjaan pada pencari kerja dan pendataan perusahaan pada Disnakertrans Kota Dumai maka dapat diambil beberapa kesimpulan yaitu sebelumnya informasi tentang lowongan pekerjaan pada Disnakertrans Kota Dumai diumukan dalam bentuk papan pengumuman, hal ini untuk mendapatkan informasi lowongan pekerjaan terbaru tidak efesien karena harus datang ke Disnakertrans Kota Dumai terlebih dahulu. Pada sistem yang baru, sistem ini memberikan fasilitas mengenai informasi lowongan pekerjaan, pencarian lowongan pekerjaan sesuai keinginan pencari kerja, pengajuan lowongan pekerjaan, pendataaan perusahaan, pendataaan lowongan pekerjaan dan dapat diakses pada website Lowongan Pekerjaan Disnakertrans Kota Dumai yang tersedia. Pencari kerja dapat melakukan pelamaran kerja pada perusahaan yang informasi lowongan pekerjaannya tersedia.

\section{REFERENSI}

Andriani, I., Ridarmin, \& Kurniawan, R. (2018). Perancangan Sistem Informasi Absensi Pegawai Pada Dinas Perdagangan Kota Dumai Menggunakan Sms Gateway. Lentera Dumai, 9(2), 15-25.

Hidayat, R. (2010). Cara Praktis Membangun Website Gratis. Jakarta: Pt. Elex Media Komputindo.

Kusrini. (2007). Strategi Perancangan Dan Pengelolaan Basis Data. Yogyakarta: Andi.

Nugroho, D. A., Zukfikar, \& Sujono. (2019). Sistem Informasi Lowongan Pekerjaan Berbasis Web. Exact Papers In Compilation, 1(2), 87-94.

Rita Afyenni. (2014). Perancangan Data Flow Diagram Untuk Sistem Informasi Sekolah ( Studi Kasus Pada Sma Pembangunan Laboratorium Unp ). Jurnal Teknoif, 2(1), 35-39.

Saputra, A., \& Agustin, F. (2013). Menyelesaikan Website 12 Juta Secara Profesional. Jakarta: Pt. Elex Media Komputindo.

Sihombing, J., \& Khumaini, H. (2016). Sistem Informasi Penjualan Game Pc Berbasis Web Pada Toko Oe Games Menggunakan Php. Jurnal Informatika Manajemen Dan Komputer, 8(2).

Tanjung, I., \& Sukrianto, D. (2017). Perancangan Sistem Informasi Rekam Medis Terpadu Dalam Upaya Meningkatkan Pelayanan Rumah Sakit Jiwa Tampan Prov. Riau. Jurnal Intra-Tech, 1(1). 